\title{
Novel tridentate diamino organomanganese(II) complexes as homogeneous catalysts in manganese(II)/copper(I) catalyzed carbon-carbon bond forming reactions
}

\author{
Johannes G. Donkervoort a, José L. Vicario a, Johann T.B.H. Jastrzebski ${ }^{\text {a }}$, \\ Robert A. Gossage a, Gérard Cahiez ${ }^{\mathrm{b}}$, Gerard van Koten ${ }^{\mathrm{a}, *}$ \\ a Department of Metal-Mediated Synthesis, Debye Institute, Utrecht University, Padualaan 8, 3584 CH Utrecht, The Netherlands \\ ${ }^{\mathrm{b}}$ Ecole Supérieure de Chimie Organique et Minerale, Département de Chimie, 13 Boulevard de l'Hautil, F-95092, Cergy-Pontoise, France
}

Received 30 August 1997

\begin{abstract}
The new, paramagnetic arylmanganese(II) complex $\mathrm{Li}\left[\mathrm{MnCl}_{2}(\mathrm{NCN})\right]\left(2, \mathrm{NCN}\left[\mathrm{C}_{6} \mathrm{H}_{3}\left(\mathrm{CH}_{2} \mathrm{NMe}_{2}\right)_{2}-2,6\right]^{-}\right)$has been obtained in high yield from the reaction of $\mathrm{MnCl}_{2}$ and $[\mathrm{Li}(\mathrm{NCN})]_{2}$ in a 2:1 molar ratio. In THF solution, 2 is likely an ionic species [ $\left.\mathrm{Li}(\mathrm{THF})_{\mathrm{n}}\right]$ $\left[\mathrm{MnCl}_{2}(\mathrm{NCN})\right]$ (molecular weight determination and conductivity measurements), while magnetic measurements indicate that a high spin $d^{5}$ manganese(II) center is present. Subsequent reaction of 2 with $\mathrm{RLi}$ afforded $[\mathrm{MnR}(\mathrm{NCN})](\mathrm{R}=\mathrm{Me}(\mathbf{3 a}), n$-Bu (3b)). Complex 2, using $\mathrm{CuCl}$ as a co-catalyst, is an effective catalyst system for cross-coupling of Grignard reagents with alkyl bromides and the 1,4-addition of organomagnesium halides to $\alpha, \beta$-unsaturated ketones. No further additives or co-solvents are necessary. For both reactions a dramatic decrease in reaction times is observed when compared to standard manganese/copper systems. Alkyl bromides with unsaturated or heteroatom functionalities can be cross-coupled. Also, excellent reactivity towards normally unreactive $\beta, \beta$-disubstituted ketones has been observed in the 1,4-addition reaction. (C) 1998 Elsevier Science S.A. All rights reserved.
\end{abstract}

Keywords: Manganese; Aryl-manganese; Cross-coupling catalyst; Grignard reagents

\section{Introduction}

Recent studies have shown that organomanganese(II) complexes are excellent reagents in a range of $\mathrm{C}-\mathrm{C}$ bond forming reactions [1]. These reagents are more stable than many organotransition metal complexes and are easily prepared from the reaction of (cheap) manganese(II) halides with Grignards or organolithium compounds ([1]a,d). Reactions that can be performed using organomanganese(II) reagents (with $\mathrm{CuX}$ in catalytic amounts) include acylation, 1,2-addition, 1,4-addition, enolization, alkylation, alkenylation and arylation $([1] \mathrm{d}, \mathrm{e})$. These reactions proceed with good to excellent chemoselectivity under mild conditions (ether solvents, $0^{\circ} \mathrm{C}$ to ambient temperature). The high chemoselectivity of organomanganese(II) reagents, combined with an

\footnotetext{
* Corresponding author.
}

excellent functional group tolerance, allows the selective conversion of, for example, ketoaldehydes to ketoalcohols, keto-carboxylic acid chlorides to diketones, unsymmetrical diketones to ketoalcohols as well as the substitution of $\omega$ halogenoketones or $\omega$ ketoalkenyl halides ([1]d).

The binding of a non-transferable, chiral ligand and a transferable organic anion to the manganese center is required to make organomanganese(II) reagents useful for the enantioselective synthesis of organic products. This strategy, which is well-known in cuprate chemistry [2], has so far not been applied in manganese(II) chemistry as suitable non-transferable groups were not available ${ }^{1}$.

\footnotetext{
${ }^{1}$ In contrast, this strategy has led to the use of chiral manganese(III) Schiff-base complexes in, for example, enantioselective epoxidation reactions [3].
} 
We have set out to explore the use of our monoanionic, bis(amino)aryl $\left[\mathrm{C}_{6} \mathrm{H}_{3}\left(\mathrm{CH}_{2} \mathrm{NMe}_{2}\right)_{2}-2,6\right]^{-} \quad(=$ $\mathrm{NCN}$; Fig. $\left.1 \quad \mathrm{~A}, \quad \mathrm{R}^{1}=\mathrm{Me}, \quad \mathrm{R}^{2}=\mathrm{R}^{3}=\mathrm{H}\right) \quad$ and bis(phosphino)aryl $\quad\left[\mathrm{C}_{6} \mathrm{H}_{3}\left(\mathrm{CH}_{2} \mathrm{PPh}_{2}\right)_{2}-2,6\right]^{-} \quad(=\mathrm{PCP}$; Fig. $1 \mathrm{~B}, \mathrm{R}=\mathrm{Ph}$ ) ligands as auxiliaries (i.e. non-transferable groups) for catalytically-active metal centers. For example, the nickel complex $[\mathrm{Ni}(\mathrm{NCN}) \mathrm{X}](\mathrm{X}=\mathrm{Cl}$, $\mathrm{Br}$ ), has already found use in the selective 1:1 Kharasch addition reaction of haloalkanes to alkenes $([4] \mathrm{a}-\mathrm{e})$ as well as in the controlled living radical polymerization of olefins ([4]f). Some $\mathrm{NCN}-$ and $\mathrm{PCP}-\mathrm{Ru}^{\mathrm{II}}$ complexes, such as $\left[\mathrm{RuCl}(\mathrm{NCN})\left(\mathrm{PPh}_{3}\right)\right],\left[\mathrm{RuCl}(\mathrm{PCP})\left(\mathrm{PPh}_{3}\right)\right]$ and $[\mathrm{RuCl}(\mathrm{OTf})(\mathrm{PCP})]$, are excellent catalysts for selective transfer hydrogenation and hydrogenation catalysis [5]. The bis(phosphino)aryl-rhodium and -iridium complexes $\left[\mathrm{M}\left\{\mathrm{C}_{6} \mathrm{H}_{3}\left(\mathrm{CH}_{2} \mathrm{P}(t-\mathrm{Bu})_{2}\right)_{2}-2,6\right\}\left(\mathrm{H}_{4}\right)\right](\mathrm{M}=\mathrm{Rh}, \mathrm{Ir})$ are unique transfer dehydrogenation catalysts for the conversion of alkanes to alkenes using, for example, 3,3-dimethylbutene as hydrogen acceptor [6].

In the present study, we report on the synthesis of $\mathrm{NCN}$-manganese(II) complexes and the use of the $\mathrm{NCN}$ ligand as a non-transferable group in manganese/ copper-mediated $\mathrm{C}-\mathrm{C}$ bond forming reactions. The effect of the use of the NCN ligand is that the reactions become (i) catalytic in manganese, (ii) highly selective and easier to study as, except for $\mathrm{CuX}$, no further additives or co-solvents are needed, and (iii) require much shorter reaction times when compared to literature procedures ${ }^{2}$.

\section{Results and discussion}

\subsection{Synthesis and characterization of two NCN-manganese(II) complexes}

The transmetallation reaction of $[\mathrm{Li}(\mathrm{NCN})]_{2}(\mathbf{1})$ with two equivalents of $\mathrm{MnCl}_{2}$ affords a novel arylmanganese compound (2), which was isolated as a yellow green solid (Eq. 1). Elemental analysis of 2 indicated a molecular stoichiometry corresponding to $\mathrm{Li}[\mathrm{Mn}-$ $\mathrm{Cl}_{2}(\mathrm{NCN})$, i.e. to a manganate complex. The reaction of 2 with $\mathrm{D}_{2} \mathrm{O}$ afforded quantitatively 2-deuterio-1,3 bis[(dimethylamino)methyl]benzene. This is further evidence for the presence of a metal-carbon bond. Unfortunately, the paramagnetic character of $\mathbf{2}$ prevented structural characterization by NMR spectroscopy. However, by using the Evans method [8], a magnetic moment of $5.95 \mathrm{BM}$ was measured for a THF solution of 2 , indicating the presence of a high spin $d^{5}$ manganese(II) metal center.

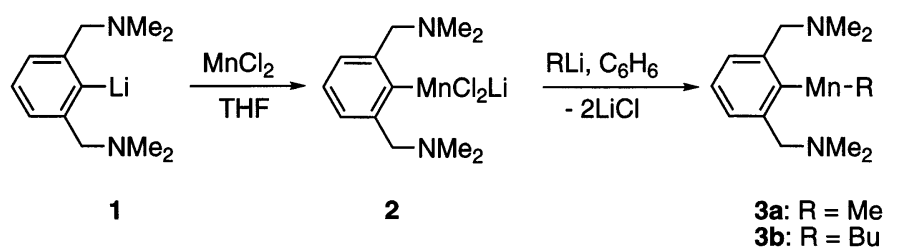

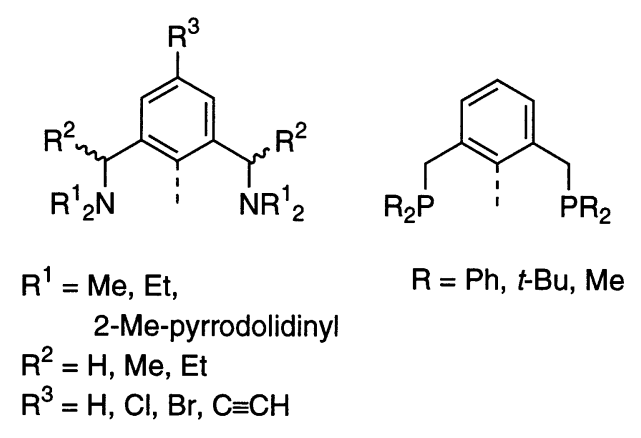

A

B

Fig. 1. Structures of bis(amino)aryl and bis(phosphino)aryl ligand systems.

\footnotetext{
${ }^{2}$ A preliminary report concerning the cross-coupling reaction has appeared [7].
}

Complex $\mathbf{2}$ is only slightly soluble in non-polar solvents like benzene but readily soluble in THF. The value of the measured degree of association was 0.5 (cryoscopy in THF [9]). This strongly suggests that $\mathbf{2}$ exists in THF either as a 1:1 mixture of two neutral species, $[\mathrm{MnCl}(\mathrm{NCN})]$ and $\mathrm{LiCl}$, or as a manganate consisting of a $\left[\mathrm{MnCl}_{2}(\mathrm{NCN})\right]$ anion and a $\left[\mathrm{Li}(\mathrm{THF})_{\mathrm{n}}\right]$ cation. Conductivity measurements of THF solutions of $\mathbf{2}$ at room temperature revealed a molar conductivity $\left(\Lambda_{\mathrm{m}}\right)$ value of $0.0206 \mathrm{~cm}^{2} \Omega^{-1} \mathrm{~mol}^{-1}$. This is significantly larger than that of $\mathrm{LiCl}$ and $[\mathrm{Li}(\mathrm{NCN})]_{2}$ (see Section 3). This result strongly suggests that $\mathbf{2}$ is likely an ionic species such as $\left[\mathrm{Li}(\mathrm{THF})_{\mathrm{n}}\right]\left[\mathrm{MnCl}_{2}(\mathrm{NCN})\right]$.

Subsequent reaction of 2 with $\mathrm{MeLi}$ or $n$-BuLi affords the corresponding heteroleptic diorganomanganese compounds 3a and $\mathbf{3 b}$, respectively (see Eq. 1). After work-up (see Section 3) these compounds were isolated as extremely air sensitive, paramagnetic, green colored oils. The compounds are readily soluble in both polar and non-polar solvents. The absence of $\mathrm{LiCl}$ in samples of $\mathbf{3 a}-\mathbf{b}$ became evident from the qualitative 
analysis for both $\mathrm{Li}$ and halogen. Like 2 , the reaction of 3a-b with $\mathrm{D}_{2} \mathrm{O}$ affords 2-deuterio-1,3-bis[(dimethylamino)methyl]benzene in quantitative yield. Due to the extreme sensitivity of $\mathbf{3}$ to air, no molecular weight determinations (cryoscopy) were performed.

Although the structural features of $\mathbf{2}$ and $\mathbf{3}$ are not known, it is likely that $\mathbf{2}$ has a five-coordinate Mn-center as a result of additional intramolecular $\mathrm{Mn}-\mathrm{N}$ coordination. The formation of organometallic aggregates with lithium halides like $\mathrm{LiCl}$ is not unprecedented. For example, the lutetium complex $\left[\mathrm{LuCl}_{2}(\mathrm{NCN}) \mathrm{LiCl}\right]_{2}$ has been isolated and the structure established by an X-ray crystal structure determination [10]. The proposed monomeric structure of $\mathbf{3}$ would resemble that of analogous $\left[\mathrm{Sn}^{\mathrm{II}} \mathrm{R}(\mathrm{NCN})\right]$ complexes [11]. However, aggregate structures are also feasible, as shown by examples of organomanganese complexes in which organic groups are bridging two Mn centers [12]. In species of general formula $[\mathrm{MnR}(\mathrm{NCN})]$, the $\mathrm{R}$ group could be involved in the latter kind of binding, in addition to the NCN ligand [13], e.g. the aggregated organocopper/copper halide complex $\left[\mathrm{Cu}_{4} \mathrm{Br}_{2}(\mathrm{NCN})_{2}\right]$ [14].

The catalytic activity of the new organomanganese species $\mathbf{2}$ and $\mathbf{3}$ (either as pure compounds or prepared in situ) were tested in cross-coupling reactions of Grignard reagents with organic bromides as well as in 1,4 -addition reactions of Grignard reagents to $\alpha, \beta$-unsaturated ketones.

\subsection{Homogeneous catalysis with $\left[\mathrm{Li}(\mathrm{THF})_{n}\right]\left[\mathrm{MnCl}_{2}(\mathrm{NCN})\right]$ and $[\mathrm{MnR}(\mathrm{NCN})]$}

Addition of a Grignard reagent to a solution of an organic bromide in THF at $5^{\circ} \mathrm{C}$ in the presence of 10 $\mathrm{mol} \%$ of 2 and $5 \mathrm{~mol} \%$ of $\mathrm{CuCl}$ affords after $15 \mathrm{~min}$ reaction time and work-up (see Section 3), the crosscoupled products with excellent chemoselectivity and high yield, see Table 1.

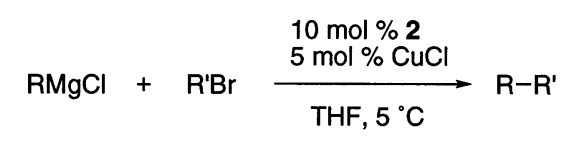

Under the reaction conditions (all Grignard reagent is added at once) it is most likely that, prior to the cross-coupling reaction, the organomanganese halide $\mathbf{2}$ is converted to a heteroleptic diorganomanganese compound 3 (see Eq. 1). These compounds are probably involved in the subsequent cross-coupling reaction. In order to test this hypothesis, we have carried out the reaction of $n-\mathrm{C}_{8} \mathrm{H}_{17} \mathrm{Br}$ with $n-\mathrm{BuMgCl}$ under identical reaction conditions but now using either pure or in situ prepared 2, and pure $\mathbf{3 b}$, (see entries 2, 1 and 3, respectively, in Table 1). Because these reactions af-
Table 1

Product yields of $\mathrm{R}-\mathrm{R}^{\prime}$ obtained from cross-coupling reactions of Grignard reagents with alkyl bromides ${ }^{\mathrm{a}}$

\begin{tabular}{llll}
\hline Entry & Alkyl bromide & Grignard reagent & Yield (\%) \\
\hline 1 & $n-\mathrm{C}_{8} \mathrm{H}_{17} \mathrm{Br}$ & $n-\mathrm{BuMgCl}$ & 83 \\
$2^{\mathrm{b}}$ & $n-\mathrm{C}_{8} \mathrm{H}_{17} \mathrm{Br}$ & $n-\mathrm{BuMgCl}$ & 83 \\
$3^{\mathrm{c}}$ & $n-\mathrm{C}_{8} \mathrm{H}_{17} \mathrm{Br}$ & $n-\mathrm{BuMgCl}$ & 83 \\
$4^{\mathrm{d}}$ & $n-\mathrm{C}_{8} \mathrm{H}_{17} \mathrm{Br}$ & $n-\mathrm{BuMgCl}$ & 62 \\
$5^{\mathrm{e}}$ & $n-\mathrm{C}_{8} \mathrm{H}_{17} \mathrm{Br}$ & $n-\mathrm{BuMgCl}$ & 55 \\
$6^{\mathrm{f}}$ & $n-\mathrm{C}_{8} \mathrm{H}_{17} \mathrm{Br}$ & $n-\mathrm{BuMgCl}$ & 70 \\
7 & $n-\mathrm{C}_{8} \mathrm{H}_{17} \mathrm{Br}$ & $i-\mathrm{PrMgCl}$ & 75 \\
8 & $n-\mathrm{C}_{8} \mathrm{H}_{17} \mathrm{Br}$ & $t-\mathrm{BuMgCl}$ & 84 \\
9 & $n-\mathrm{C}_{8} \mathrm{H}_{17} \mathrm{Br}$ & $s-\mathrm{BuMgCl}$ & 92 \\
10 & $n-\mathrm{C}_{4} \mathrm{H}_{9} \mathrm{CH}(\mathrm{Me}) \mathrm{Br}$ & $n-\mathrm{EtMgCl}$ & 94 \\
11 & $n-\mathrm{C}_{4} \mathrm{H}_{9} \mathrm{CO}\left(\mathrm{CH}_{2}\right)_{10} \mathrm{Br}$ & $n-\mathrm{BuMgCl}$ & 91 \\
12 & $n-\mathrm{C}_{2} \mathrm{H}_{5} \mathrm{OC}(\mathrm{O})(\mathrm{CH})_{2} \mathrm{Br}$ & $n-\mathrm{BuMgCl}$ & 89 \\
13 & $\mathrm{CH}_{2}=\mathrm{CH}\left(\mathrm{CH}_{2}\right)_{2} \mathrm{Br}$ & $n-\mathrm{C}_{14} \mathrm{H}_{29} \mathrm{MgCl}$ & 91 \\
14 & $\mathrm{Me}_{3} \mathrm{SiC} \mathrm{Ci}\left(\mathrm{CH}_{2}\right)_{2} \mathrm{Br}$ & $n-\mathrm{C}_{14} \mathrm{H}_{29} \mathrm{MgCl}$ & 89 \\
\hline
\end{tabular}

${ }^{a}$ Unless otherwise stated; catalyst $10 \mathrm{~mol} \%$ of in situ prepared 2, 5 mol $\%$ CuCl. ${ }^{\mathrm{b}} 10 \mathrm{~mol} \%$ pure $2,5 \mathrm{~mol} \% \mathrm{CuCl} .{ }^{\mathrm{c}} 10 \mathrm{~mol} \%$ pure $\mathbf{3 b}, 5$ $\mathrm{mol} \% \mathrm{CuCl} .{ }^{\mathrm{d}} 10 \mathrm{~mol} \% \mathrm{2}, 2.5 \mathrm{~mol} \% \mathrm{CuCl} .{ }^{\mathrm{e}} 12 \mathrm{~mol} \% \mathrm{2}, 2 \mathrm{~mol} \%$ $\mathrm{CuCl} .{ }^{\mathrm{f}} 10 \mathrm{~mol} \% 2,10 \mathrm{~mol} \% \mathrm{CuCl}$.

forded essentially the same products in identical yields, further reactions were carried out simply using in situ prepared 2 (i.e. addition of one equivalent of $\mathrm{MnCl}_{2}$ to 1).

Primary, secondary and tertiary alkyl Grignard reagents reacted successfully (see entries 7-9 in Table 1). Specifically, the reaction with secondary alkyl Grignard reagents (entry 7) is notable. Our newly developed procedure affords the cross-coupled product in excellent yield $(92 \%)$, whereas a similar reaction using the classical $\mathrm{Li}_{2} \mathrm{CuCl}_{4}$ reagent afforded the cross-coupled product in only $24 \%$ yield [15]. Also, the reaction of a Grignard reagent with a secondary alkyl bromide gives rise to the formation of the cross-coupled product in high yield (entry 10). This is in contrast with the manganese-mediated [16] or copper-catalyzed procedures [17], in which these substrates do not react.

It has been well established ([1]d) that organomanganese reagents are highly chemoselective and tolerant to the presence of a variety of functional groups. These advantages are retained in our catalyst system (see entries 11 to 14 in Table 1). The presence of unsaturated functionalities (alkene or alkyne) does not influence either the selectivity or the yield of the $\mathrm{C}-\mathrm{C}$ coupled product. The corresponding unsaturated crosscoupled products were obtained in excellent yields. None or only small traces $(<5 \%)$ of olefin rearrangement products could be detected in the crude reaction mixtures. This result is of particular interest for the preparation of $\omega$-unsaturated acids, compounds which can be used for the preparation of ultra thin-layer photoresists and $\omega$-radio-iodonated fatty acids, which 
find use as myocardial imaging agents [18]. Synthetic procedures for $\omega$-unsaturated acids described in literature involve many steps and the products are not always of the required purity for photoresists synthesis because of, for example, the presence of small amounts of compounds resulting from double bond migration $[18,19]$.

Substrates containing heteroatom functionalities, e.g. ketones and esters, are tolerated by our catalyst system (entries 11 and 12, respectively). Of special interest is the excellent yield of heptanoic ethyl ester which was obtained by reacting ethyl 3-bromopropionate with $n$ $\mathrm{BuMgCl}$ (entry 12). Previous attempts to alkylate this alkyl bromo ester resulted in low yields (28\%) [20].

The applicability of $\mathrm{NCN}$-manganate $2 / \mathrm{CuX}$ as a catalytic system for the conjugate addition reactions of Grignard reagents towards enones (Eq. 3) was studied. Excellent yields and chemoselectivities for the 1,4-addition products were obtained, which appeared to be independent of the type of electrophile used (endocyclic, exo-cyclic or acyclic $\alpha, \beta$-unsaturated ketones; Table 2).

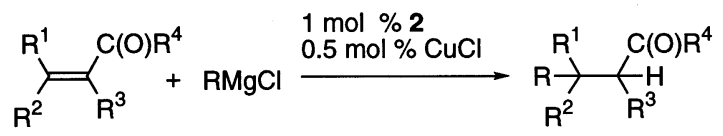

In particular, the high yields of products obtained from $\beta, \beta$-disubstituted $\alpha, \beta$-unsaturated ketones are notable (entries 1-3 in Table 2), since it is well known that these substrates undergo conjugate addition reactions with difficulty using organo-copper or cuprate reagents [21].

Table 2

Product yields of the 1,4-addition products obtained from the reaction of $\mathrm{BuMgCl}$ with conjugated enones ${ }^{\mathrm{a}}$

\begin{tabular}{ccc}
\hline Entry & Isolated yield $^{\mathrm{b}}$ \\
\hline 3 & Substrate & 90 \\
5 & 92
\end{tabular}

\footnotetext{
a Catalyst $10 \mathrm{~mol} \%$ of in situ prepared 2, $5 \mathrm{~mol} \% \mathrm{CuCl} .{ }^{\mathrm{b}}$ Isolated yield of the corresponding 1,4-addition products.
}

\subsection{Mechanistic considerations}

The present results show that with the monoanionic $\mathrm{NCN}$ ligand the above mentioned $\mathrm{C}-\mathrm{C}$ bond forming reactions become catalytic in manganese. Moreover, the reactions are much faster than the reactions mediated by stoichiometric amounts of $\mathrm{MnCl}_{2}$ and much easier to study because only a single solvent, THF or toluene, can be used and additives or activators are not required.

It was shown that a $\mathrm{D}_{2} \mathrm{O}$ quench of completed reaction mixtures provided the 2-deuterio derivative of $\mathrm{NCN}$ quantitatively. This suggests that the NCN ligand remains connected via $\mathrm{C}_{i p s o}$ to a metal center. Therefore, the $\mathrm{C}_{6} \mathrm{H}_{3}\left(\mathrm{CH}_{2} \mathrm{NMe}_{2}\right)_{2}-2,6$ anion is a potentially terdentate ligand with excellent non-transferable properties in the reactions studied here. This is not only interesting from the point of view that manganese can be used in catalytic amounts, but also that the $\mathrm{Mn}$ center is contained in the ligand framework and thus becomes subject to the steric and electronic influences exerted by the NCN ligand. Preliminary experiments with an enantiomerically enriched, modified NCN-pincer ligand [26] (see Section 3), suggest that chiral information can be transferred from the ligand in the product forming step. Unfortunately, the enantiomeric excesses of the products that are obtained are quite low.

Finally, the experiment with $\mathrm{Li}_{2} \mathrm{MnCl}_{4}$ and the free arene 1,3-bis[(dimethylamino)methyl]benzene failed to give the $\mathrm{C}-\mathrm{C}$ coupled products. This corroborates the view that the NCN ligand is bound in its deprotonated form, i.e. a metal-carbon bond is present.

The next question to be addressed is the meaning of the 2:1 atomic ratio of manganese and copper that is required. In a series of experiments, it was found that a higher $(4: 1$ or $6: 1)$ or lower $(1: 1) \mathrm{Mn}: \mathrm{Cu}$ ratio, lowers the yield of the $\mathrm{C}-\mathrm{C}$ coupled product (entries 4-6 in Table 1). In addition, in separate experiments using $\left[\mathrm{Cu}_{4} \mathrm{Br}_{2}(\mathrm{NCN})_{2}\right]$ as the copper(I) source, a much lower yield of cross-coupled product was obtained as compared to the $\mathrm{NCN}-\mathrm{Mn} / \mathrm{CuCl}$ system (see Section 3). This indicates that it is not simply a $\mathrm{NCN}-\mathrm{Cu}$ species that is the active catalyst.

It must also be noted, that substrates that have been tested with our catalyst system (entries $1-3$ in Table 2) are not reactive enough to undergo a conjugate addition with a cuprate reagent. Therefore, a magnesium cuprate species can also be excluded as the kinetically active species. Finally, the stoichiometric reaction of $\mathbf{3 b}$ with octyl bromide in the absence of copper(I) did not proceed. All this information points to a reactive intermediate that at least comprises of $\mathrm{Mn}^{\mathrm{II}}, \mathrm{NCN}$ and $\mathrm{Cu}(\mathrm{I})$ as well as the substrate and the transferable group $\mathrm{R}^{-}$.

With the present information, further conclusions about the nature of the reactive intermediate are impos- 


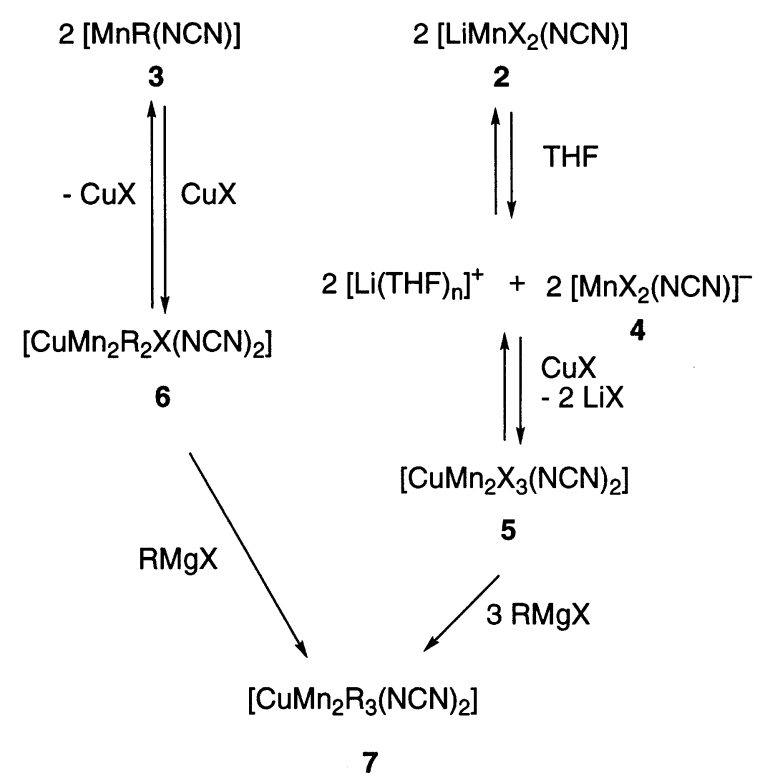

Scheme 1 . Possible equilibria in the formation of the kinetically active species in $2 / \mathrm{CuX}$ and $3 / \mathrm{CuX}$ catalyzed $\mathrm{C}-\mathrm{C}$ bond forming reactions.

sible. However, the fact that the manganate species 2 or the diorganomanganese species $\mathbf{3}$ can be used catalytically, can be explained when the equilibria in Scheme 1 are considered. Under the reaction conditions (i.e. first addition of $\mathrm{CuCl}$ to $\mathbf{2}$ or $\mathbf{3}$ ) it is likely that initially a manganese-copper species is formed (e.g. 5 or $\mathbf{6}$ ). In the presence of excess $\mathrm{RMgX}$, these intermediates could then form an organomanganate (e.g. 7; note that NCN is non-transferable probably because of chelation). A possible structure of 7 is shown in Fig. 2A, which is based on the versatile coordination properties of the $\mathrm{NCN}$ anion $^{3}$. A precedent for the bridging of $\mathrm{C}_{i p s o}$ of different Lewis acidic metal centers has been obtained for the tantalum $(\mathrm{V})$ complex $\left[\mathrm{TaCl}_{2}(\mathrm{CH}(t-\right.$ $\mathrm{Bu})(\mathrm{NCN}) \mathrm{ZnCl}]$ (established by an X-ray crystal structure determination) [22], of which the schematic structure is shown in Fig. 2B.

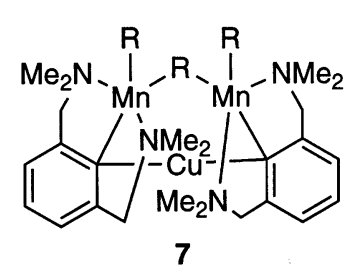

A

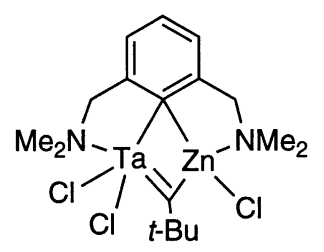

B
Fig. 2. A: Proposed structure of $\left[\mathrm{CuMn}_{2} \mathrm{R}_{3}(\mathrm{NCN})_{2}\right]$, 7; B: Molecular structure of the $\mathrm{NCN}-\operatorname{tantalum}(\mathrm{V})$ complex $\left[\mathrm{TaCl}_{2}=(\mathrm{CH}(t-\right.$ $\mathrm{Bu})(\mathrm{NCN}) \mathrm{ZnCl}$.

\footnotetext{
${ }^{3}$ Based on experimental evidence (during the reaction an excess of $\mathrm{RMgX}$ is present), the formation of negatively charged manganate species containing a higher number of R-groups may, a priori, not be excluded.
}
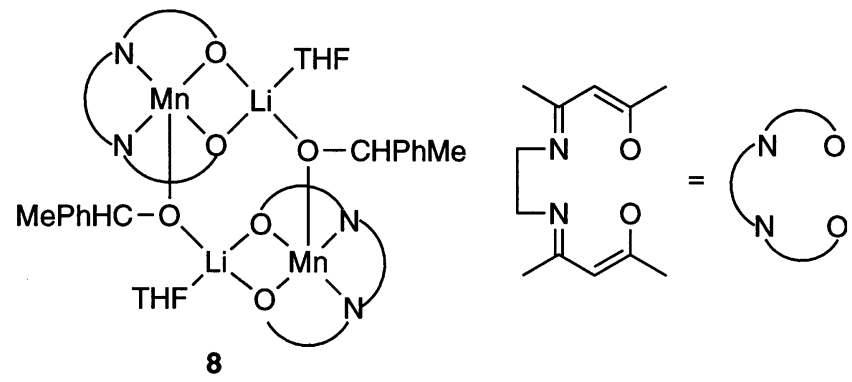

Fig. 3. Molecular structure of the isolated end-product $(\mathbf{8})$ of the 1,2-addition reaction of a methylmanganese(II) reagent with benzaldehyde.

The cross-coupling and conjugate addition reactions differ in at least one important aspect, i.e. the crosscoupling reaction produces the end-product without hydrolysis, whereas in the conjugate addition reaction a magnesium enolate is the end-product. The latter suggests that, at least in the conjugate addition reactions, magnesium cations play a role. A model of this end product has recently been proposed by Floriani et al. [23]. They isolated and characterized (X-ray analysis) an alkoxymanganate complex $\mathbf{8}$ (Fig. 3), which is the end-product of the 1,2-addition reaction of an organomanganese(II) reagent to benzaldehyde [23]. Although this manganese reagent is not catalytically active in the 1,2-addition reaction, the proposed formation of $\mathbf{8}$ [23] provides a possible intermediate structure for our catalytic system in the 1,4-addition reaction. Analogous to $\mathbf{8}$, we propose a kinetically active species 9 (Fig. 4). In this intermediate, the substrate is anchored in a bidentate fashion to the $\mathrm{CuMn}_{2}$ unit through the oxygen atom of the carbonyl unit to one of the manganese centers and via $\eta^{2}$-binding of the $\mathrm{C}=\mathrm{C}$ double bond to copper. This type of intermediate has also been postulated for the conjugate addition reactions catalyzed by arenethiolatocopper(I) complexes ([2]f). The R-group from the other manganese center of the aggregate is then ideally situated to be

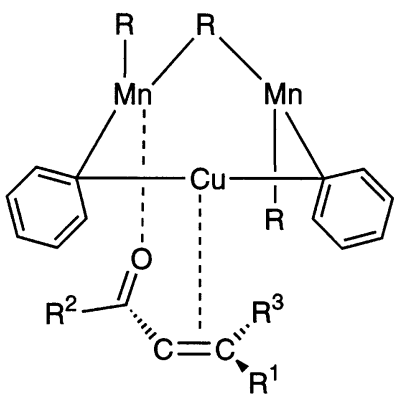

9

Fig. 4. Proposed intermediate (9) in the 1,4-addition reaction of $\left[\mathrm{CuMnR}_{3}(\mathrm{NCN})_{2}\right]$ with $\alpha, \beta$-unsaturated ketones. The $\mathrm{CH}_{2} \mathrm{NMe}_{2}$ substituents have been omitted for clarity. 


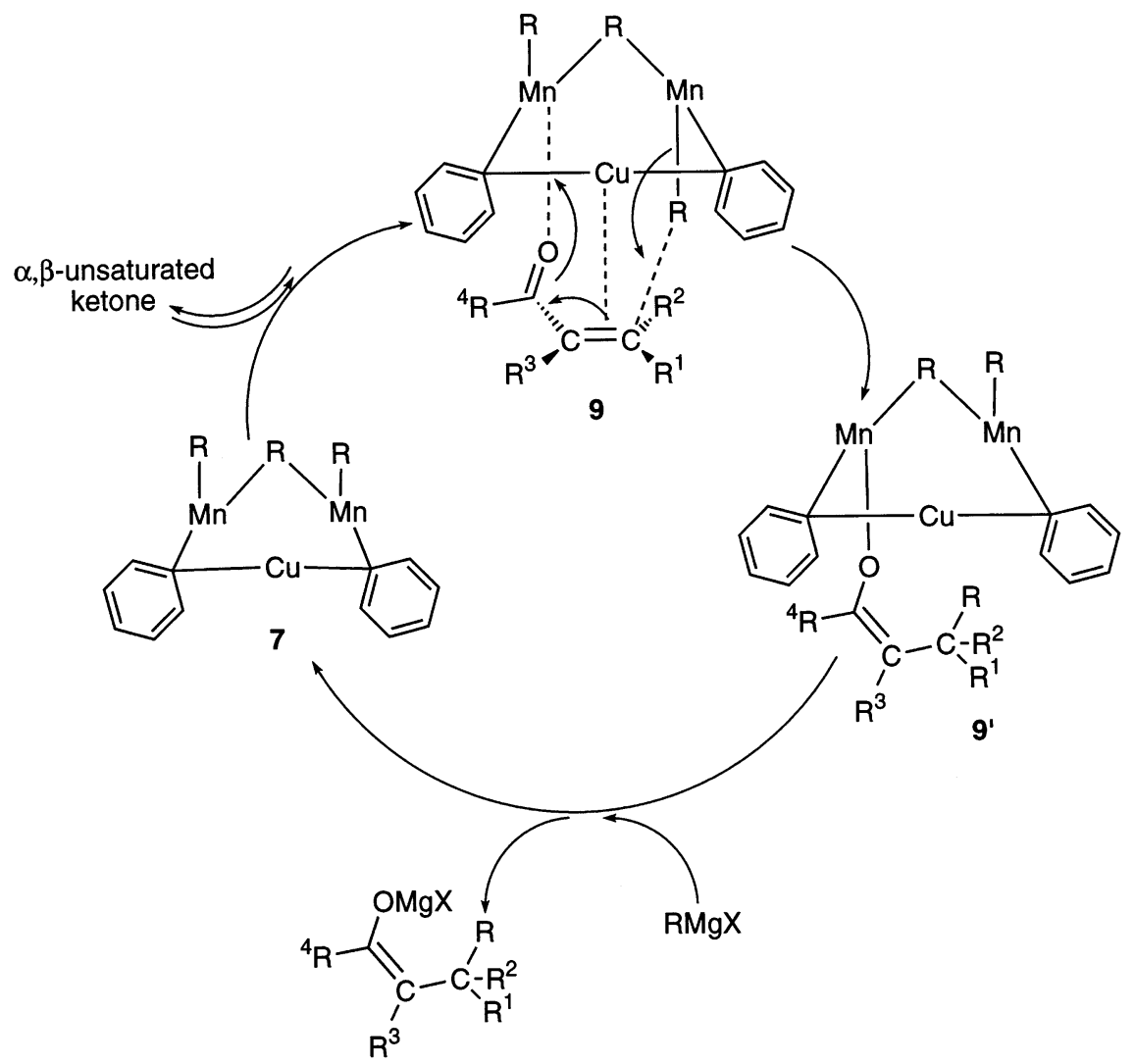

Scheme 2. Proposed catalytic cycle of the 1,4-addition reactions of $\left[\mathrm{CuMn}_{2} \mathrm{R}_{3}(\mathrm{NCN})_{2}\right]$ with $\alpha, \beta$-unsaturated ketones $\left(\right.$ the $\mathrm{CH}_{2} \mathrm{NMe}_{2}$ arms of the NCN ligand have been omitted for clarity).

transferred to the 4-position of the substrate to afford a manganese enolate complex 10 (Scheme 2). Complex 10 probably reacts with one equivalent of a Grignard reagent to afford a magnesium enolate and $\mathbf{7}$, which is capable of entering a new catalytic cycle.

The present study has provided an excellent new catalytic system for $\mathrm{C}-\mathrm{C}$ coupling reactions. In addition, some information regarding the kinetically active species, involved in manganese-copper catalyzed reactions, has been obtained. However, studies to give a further insight into the kinetically active species and mechanism of these reactions should be part of future work.

\section{Experimental section}

\subsection{General section}

All organometallic syntheses were carried out using standard Schlenk techniques under an atmosphere of dry, oxygen-free nitrogen. Solvents were carefully dried, distilled from sodium benzophenone ketyl and deoxygenated prior to use. ${ }^{1} \mathrm{H}(200$ or $300 \mathrm{MHz})$ and ${ }^{13} \mathrm{C}\left\{{ }^{1} \mathrm{H}\right\}$ (50 or $75 \mathrm{MHz}$ ) NMR spectra were recorded on a Bruker AC-200 or AC-300 spectrometer. Conductivity measurements were carried out using a Philips PW 9501 conductometer with a YSI model 3402 microcell. The compounds $\quad\left[\mathrm{Cu}_{4} \mathrm{Br}_{2}(\mathrm{NCN})_{2}\right] \quad[14]$, 4-bromo-1trimethylsilyl-1-butyne [24], [Li(NCN) $]_{2}$ ([13]a) and (R, $\left.\left.\mathrm{R}^{\prime}\right)-\left[\mathrm{LiC}_{6} \mathrm{H}_{3}\left(\mathrm{CH}(\mathrm{Et}) \mathrm{NMe}_{2}\right)_{2}-2,6\right\}\right]_{2}$ [25] were prepared according to literature procedures. Commercially obtained manganese(II) chloride tetrahydrate was dehydrated in vacuo at $120^{\circ} \mathrm{C}$ and stored under a nitrogen atmosphere.

\subsection{Preparation of $\left[\mathrm{LiMnCl}_{2}\left\{\mathrm{C}_{6} \mathrm{H}_{3}\left(\mathrm{CH}_{2} \mathrm{NMe}_{2}\right)_{2}-2,6\right\}\right]$, 2}

To a suspension of $\mathrm{MnCl}_{2}(11.60 \mathrm{mmol})$ in THF (25 $\mathrm{ml})$, a solution of $[\mathrm{Li}(\mathrm{NCN})]_{2}(5.8 \mathrm{mmol})$ in THF $(5 \mathrm{ml})$ was added after which the mixture was stirred for 15 min at room temperature. The solvent was then evaporated in vacuo to give a dark oil. The oil was washed with pentanes $(2 \times 25 \mathrm{ml})$ and dried in vacuo to give $2.76 \mathrm{~g}(73 \%)$ of 2 as a yellow/green colored solid. Anal. Calc. (found) for $\mathrm{C}_{12} \mathrm{H}_{19} \mathrm{Cl}_{2} \mathrm{LiMnN}_{2}$ : C, 44.47 (44.40); H, 5.91 (6.05); N, 8.64 (8.66).

\subsubsection{Cryoscopy measurements}

The cryoscopic measurements were conducted according to a literature procedure [9] using a S2541 
thermolyzer and a metal-mantled Pt-100 sensor. For the calibration, naphthalene was used to give the following cryoscopic constant $E_{\mathrm{k}}=1.52 \mathrm{~K} \mathrm{~kg} \mathrm{~mol}^{-1}$. The addition of $\mathbf{2}$ as weighed tablets took place under nitrogen atmosphere and after dissolution, the freezing point was determined (three repetitions). The concentration of 2 was varied between 0 and 50 mmolal.

\subsubsection{Determination magnetic moment of $\mathbf{2}$ by the \\ Evan's method}

In a typical experiment, a NMR tube was filled with ca. $25 \mathrm{mg}$ of $2,1 \mathrm{ml}$ of THF and $1 \mathrm{mg}$ of durene. The shift of the durene signals was determined by comparing the durene signals with those of a solution of $1 \mathrm{mg}$ of durene in THF $(1 \mathrm{ml})$. The formulae as derived by Evans [8] allowed for the calculation of the magnetic moment of 2.

\subsubsection{Conductivity measurements of $\mathbf{2}$}

In a typical experiment, the conductivity $\left(\Omega_{\mathrm{m}}\right)$ of a solution of 3 (ca. $10^{-3} \mathrm{M}$ ) in THF at room temperature was found to be $2.06 \times 10^{-2} \mathrm{~cm}^{2} \Omega^{-1} \mathrm{~mol}^{-1}$. For comparison $\mathrm{LiCl}$ and $[\mathrm{Li}(\mathrm{NCN})]_{2}$ were measured in the same system, which gave molar conductivity values of $9 \times 10^{-5}$ and $1.3 \times 10^{-5} \mathrm{~cm}^{2} \Omega^{-1} \mathrm{~mol}^{-1}$, respectively.

\subsection{Preparation of $\left[\mathrm{Mn}\left\{\mathrm{C}_{6} \mathrm{H}_{3}\left(\mathrm{CH}_{2} \mathrm{NMe}_{2}\right)_{2}-2,6\right\} \mathrm{R}\right], \mathbf{3}$}

In a typical experiment a solution of either $\mathrm{RLi}(5.0$ $\mathrm{mmol} ; \mathrm{R}=\mathrm{Me}, n-\mathrm{Bu})$ in hexanes or $\mathrm{RMgCl}(5.0 \mathrm{mmol}$; $\mathrm{R}=n-\mathrm{Bu})$ in $\mathrm{THF}$, was added to a solution of $2(5.0$ $\mathrm{mmol})$ in $\mathrm{C}_{6} \mathrm{H}_{6}(25 \mathrm{ml})$ at ambient temperature. The mixture was stirred for $5 \mathrm{~min}$. The resulting salt that was formed was removed by centrifugation of the reaction mixture and decantation of the organic layer. The remaining solid was extracted with $\mathrm{C}_{6} \mathrm{H}_{6}(3 \times 25 \mathrm{ml})$. The combined organic fractions were then evaporated in vacuo to give $\mathbf{3}$ as off-green colored oils. Yield: 1.20 g $(92 \%)$ 3a, $1.44 \mathrm{~g}(95 \%)$ 3b. Due to the extreme sensitivity to air, no elemental analysis have been performed of these products.

\subsection{General procedure for cross-coupling reactions catalyzed by the $\mathbf{2} / \mathrm{CuCl}$ catalytic system}

In a typical experiment, copper(I) chloride $(0.5$ mmol) was added to a clear solution of 2 prepared in situ $(1.0 \mathrm{mmol})$ in THF $(25 \mathrm{ml})$. The reaction mixture was cooled to $5^{\circ} \mathrm{C}$. Addition of the appropriate alkyl bromide $(10 \mathrm{mmol})$ was followed by the rapid addition (30 s) of the Grignard reagent $(10 \mathrm{mmol})$ dissolved in THF. The resulting mixture was then stirred for another $15 \mathrm{~min}$ at $5^{\circ} \mathrm{C}$ and then hydrolyzed with $50 \mathrm{ml}$ of $4 \mathrm{M} \mathrm{HCl}$ (aq.). The organic layer was separated and the aqueous layer was extracted with pentanes $(4 \times 25 \mathrm{ml})$.
The combined organic fractions were washed with a saturated aqueous $\mathrm{NaHCO}_{3}$ solution $(1 \times 25 \mathrm{ml})$ and dried $\left(\mathrm{MgSO}_{4}\right)$. The products were isolated as colourless liquids by flash distillation and were identified by comparison of their GC, MS and NMR data with those of authentic samples. Dodecane: yield $1.41 \mathrm{~g}(83 \%)$. 2-Methyldecane: yield 1.17 g (75\%). 2,2-Dimethyldecane: yield $1.43 \mathrm{~g}(84 \%)$. 3-Methylundecane: yield 1.20 g (94\%). 3-Methyloctane: yield 1.20 g (94\%). 5Methyldec-1-ene: yield $1.36 \mathrm{~g}$ (87\%). Heptanoic ethyl ester: yield $1.41 \mathrm{~g}(89 \%)$. Octadec-1-ene: yield $2.29 \mathrm{~g}$ (91\%). 1-(Trimethylsilyl)-octadec-1-yne: yield $2.87 \mathrm{~g}$ $(89 \%)$.

\section{5. $[\mathrm{MnBu}(\mathrm{NCN})] / \mathrm{CuCl}$-catalyzed cross-coupling reaction with octyl bromide}

The procedure was identical to that described above for the $2 / \mathrm{CuCl}$-catalyzed cross-coupling reactions except that a solution of $[\mathrm{Mn}(n-\mathrm{Bu})(\mathrm{NCN})](1.0 \mathrm{mmol})$ and $\mathrm{CuCl}(0.5 \mathrm{mmol})$ in THF $(25 \mathrm{ml})$ was used. The product(s) were identified by comparison of the GC, MS and NMR data with those of an authentic sample.

\subsection{Use of $\left[\mathrm{Cu}_{4} \mathrm{Br}_{2}(\mathrm{NCN})_{2}\right]$ as catalyst}

$n$-Octyl bromide $(2.86 \mathrm{mmol})$ and $i$-PrMgCl $(2.86$ mmol, $1.43 \mathrm{ml}$ of a $2.0 \mathrm{M}$ solution in THF) were added to a solution of $\left[\mathrm{Cu}_{4} \mathrm{Br}_{2}(\mathrm{NCN})_{2}\right](0.14 \mathrm{mmol})$ in THF $(25 \mathrm{ml})$ at a temperature of $5^{\circ} \mathrm{C}$. After stirring the reaction mixture for $1 \mathrm{~h}$ at this temperature, the reaction mixture was hydrolyzed with $50 \mathrm{ml}$ of $4 \mathrm{M} \mathrm{HCl}$ (aq.). The work up procedure was identical as that described for the corresponding $\mathbf{2} / \mathrm{CuCl}$-catalyzed crosscoupling reaction. Yield: $0.24 \mathrm{~g}(54 \%)$. The product was identified by comparison of the GC, MS and NMR data with those of an authentic sample.

\subsection{General procedure for \\ $\left[\mathrm{Li}(\mathrm{THF})_{n}\right]\left[\mathrm{MnCl}_{2}(\mathrm{NCN})\right] / \mathrm{CuCl}$-catalyzed conjugate 1,4-addition reactions}

To a solution of 2 (1.0 mmol), copper(I) chloride (0.5 $\mathrm{mmol})$ and the appropiate electrophile $(10 \mathrm{mmol})$ in 25 $\mathrm{ml}$ of THF, was added drop-wise the Grignard reagent (10 mmol) dissolved in THF at such a rate that the temperature of the reaction mixture did not exceed $7^{\circ} \mathrm{C}$. Complete addition of the Grignard reagent was followed by stirring the reaction mixture for $45 \mathrm{~min}$ at $5^{\circ} \mathrm{C}$. The mixture was then quenched with $100 \mathrm{ml}$ of 4 $\mathrm{M} \mathrm{HCl}$ (aq.). The organic layer was separated and the aqueous layer extracted with $\mathrm{Et}_{2} \mathrm{O}(3 \times 30 \mathrm{ml})$. The combined organic fractions were washed with a saturated aqueous $\mathrm{NaHCO}_{3}$ solution $(30 \mathrm{ml})$ and dried 
$\left(\mathrm{MgSO}_{4}\right)$. The crude product(s) were purified by flash distillation and identified by comparing their GC, MS and NMR data with those of authentic samples. 3Butyl-3-methyl-5,5-dimethyl-cyclohexanone: yield 1.76 g (90\%). 3-(1,1-Dimethyl-pentyl)-5 methyl-cyclohexanone: yield $2.28 \mathrm{~g}$ (92\%). 4,4-Dimethyloctan-2-one: yield $1.36 \mathrm{~g}(87 \%)$. 4-Phenyloctan-2-one: yield $1.75 \mathrm{~g}$ (86\%). 3-Butylcyclohexanone: yield $1.40 \mathrm{~g}(91 \%)$.

\subsection{General procedure for enantioselective 1,4-addition reactions}

(A) In THF: the procedure was identical to that described for the $2 / \mathrm{CuCl}$-catalyzed 1,4-addition reactions, starting from in situ prepared $\left[\mathrm{MnCl}_{2}\left\{\mathrm{C}_{6} \mathrm{H}_{3}\left(\mathrm{CH}(\mathrm{Et}) \mathrm{NMe}_{2}\right)_{2}-2,6\right\}\right]$ (9) by reacting (R, $\mathrm{R})-\left[\mathrm{Li}\left\{\mathrm{C}_{6} \mathrm{H}_{3}\left(\mathrm{CH}(\mathrm{Et}) \mathrm{NMe}_{2}\right)_{2}-2,6\right\}\right]_{2}(9)(0.5 \mathrm{mmol})$ and $\mathrm{MnCl}_{2}(1.0 \mathrm{mmol})$ in THF $(25 \mathrm{ml})$ at ambient temperature. (B) In toluene: the arylmanganese(II) complex 9 was prepared in an identical way to that described for 2, starting from $\mathbf{1 0}(0.5 \mathrm{mmol})$ and $\mathrm{MnCl}_{2}(1.0 \mathrm{mmol})$. After $30 \mathrm{~min}$, all volatiles were removed from the reaction mixture in vacuo. The residue was washed with pentanes $(2 \times 25 \mathrm{ml})$ and then dissolved in toluene $(25 \mathrm{ml})$. The work-up procedure was identical to that described above for the 2/CuCl-catalyzed 1,4-addition reaction. 4-Phenyloctan2-one: yield $1.75 \mathrm{~g}(86 \%)$. The $\%$ e.e. value $(4 \%$ in THF, $8 \%$ in $\mathrm{C}_{7} \mathrm{H}_{8}$ ) was determined from the ${ }^{13} \mathrm{C}\left\{{ }^{1} \mathrm{H}\right\}$ NMR data of the diastereoisomeric ketal, which is formed from the crude product according to a literature procedure [26,27]. 3-Butylcyclohexanone: yield $1.40 \mathrm{~g}(91 \%)$. The $\%$ e.e. value $\left(11 \%\right.$ in $\left.\mathrm{C}_{7} \mathrm{H}_{8}\right)$ was determined in a similar way.

\subsection{Attempted 1,4-addition reaction using a $\left[\mathrm{Li}_{2} \mathrm{MnCl}_{4} / \mathrm{NC}(\mathrm{H}) \mathrm{N}\right]$ system}

The 1,3-bis[(dimethylamino)methyl]benzene (14.5 mmol) was added to a freshly prepared solution of $\left[\mathrm{Li}_{2} \mathrm{MnCl}_{4}\right](14.5 \mathrm{mmol})$ in THF $(50 \mathrm{ml})$. Immediately, an off-white precipitate formed. To this suspension copper(I) chloride $(1.72 \mathrm{mmol})$ and pulegone (48.3 $\mathrm{mmol})$ were subsequently added at $5^{\circ} \mathrm{C}$. The Grignard reagent $(25.6 \mathrm{ml}$ of a $1.95 \mathrm{M}$ solution in THF) was added drop-wise at such a rate that the temperature did not exceed $7^{\circ} \mathrm{C}$. Complete addition of the Grignard reagent was followed by stirring the reaction mixture for $45 \mathrm{~min}$ at $5^{\circ} \mathrm{C}$. The reaction mixture was quenched with $100 \mathrm{ml}$ of $4 \mathrm{M} \mathrm{HCl}$ (aq.). The work up procedure was identical to the corresponding $\mathbf{2} /$ CuCl-catalyzed 1,4-addition reaction to give an intractable mixture of high boiling products.

\section{Acknowledgements}

This work was supported in part (JGD) by the Netherlands Foundation for Chemical Research (SON) with financial aid from the Netherlands Organization for Scientific Research (NWO).

\section{References}

[1] (a) J.F. Normant, G. Cahiez, in: R. Scheffold (Ed.), Modern Synthetic Methods, vol. 3, Wiley, Chichester, UK, 1983, p. 173. (b) M.T. Reetz, K. Röfing, N. Griebenow, Tetrahedron Lett. 35 (1994) 1969. (c) C. Kiefl, A. Mannschreck, Synthesis (1995) 1033. (d) Review: G. Cahiez, in: L. Paquette (Ed.), Encyclopedia of Reagents for Organic Synthesis, Wiley, Chichester, 1995, p. 925. (e) I. Klement, H. Stadtmüller, P. Knochel, G. Cahiez, Tetrahedron Lett. 38 (1997) 1927.

[2] (a) B.H. Lipshutz, G. Bulow, R.F. Lowe, K.L. Stevens, J. Am. Chem. Soc. 118 (1996) 5512. (b) A.H.M. de Vries, A. Meetsma, B.L. Feringa, Angew. Chem. Int. Ed. Engl. 35 (1996) 2374. (c) A. Pfaltz, Acta Chem. Scand. 50 (1996) 189. (d) U. Koop, G. Handke, N. Krause, Liebigs Ann. 10 (1996) 1487. (e) J.E. Bäckvall, Acta Chem. Scand. 50 (1996) 661. (f) M. van Klaveren, E.S.M. Persson, A. DelVillar, D.M. Grove, J.E. Bäckvall, G. van Koten, Tetrahedron Lett. 36 (1995) 3059.

[3] (a) W. Zhang, J.L. Loebach, S.R. Wilson, E.N. Jacobsen, J. Am. Chem. Soc. 112 (1990) 2801. (b) E.N. Jacobsen, W. Zhang, M.L. Güler, Ibid 113 (1991) 6703.

[4] (a) G. van Koten, Pure Appl. Chem. 61 (1989) 1681. (b) M.H.P. Rietveld, D.M. Grove, G. van Koten, New J. Chem. 21 (1997) 751. (c) D.M. Grove, A.H.M. Verschuuren, G. van Koten, J.A.M. van Beek, J. Organomet. Chem. 372 (1989) C1. (d) J.A.M. van Beek, G. van Koten, M.J. Ramp, et al., Inorg. Chem. 30 (1991) 3059. (e) J.W.J. Knapen, A.W. van der Made, J.C. de Wilde, P.W.M.N. van Leenwen, P. Wijkens, D.M. Grove, G. van Koten, Nature 372 (1994) 659. (f) C. Granel, Ph. Dubois, R. Jérôme, Ph. Teyssié, Macromolecules 29 (1996) 8576.

[5] P. Dani, T. Karlen, G. van Koten, in preparation.

[6] (a) M. Gupta, C. Hagen, R.J. Flesher, W.C. Kaska, C.M. Jensen, Chem. Commun., (1996) 2083 (Corrigendum: Edam, Ibid (1996) 2687). (b) M. Gupta, W.C. Kaska, C.M. Jensen, Ibid (1997) 461.

[7] J.G. Donkervoort, J.L. Vicario, J.T.B.H. Jastrzebski, G. Cahiez, G. van Koten, Recl. Trav. Chim. Pays-Bas 115 (1996) 547.

[8] (a) D.F. Evans, J. Chem. Soc. (1959) 2003. (b) J. Loliger, R. Scheffold, J. Chem. Ed. 49 (1972) 646.

[9] A. Gerold, J.T.B.H. Jastrzebski, C.M.P. Kronenburg, N. Krause, G. van Koten, Angew. Chem. Int. Ed. Engl. 36 (1997) 755.

[10] M.P. Hogerheide, D.M. Grove, J. Boersma, J.T.B.H. Jastrzebski, H. Kooijman, A.L. Spek, G. van Koten, Chem. Eur. J. 1 (1995) 343.

[11] J.T.B.H. Jastrzebski, P.A. van der Schaaf, J. Boersma, G. van Koten, Organometallics 8 (1989) 1373.

[12] T.C. Flood, in: C.P. Casey (Ed.), Comprehensive Organometallic Chemistry, vol. 6, Oxford, Elsevier, 1995.

[13] (a) J.T.B.H. Jastrzebski, G. van Koten, M. Konijn, C.H. Stam, J. Am. Chem. Soc. 104 (1982) 5490. (b) P. Steenwinkel, S.L. James, D.M. Grove, N. Veldman, A.L. Spek, G. van Koten, Chem. Eur. J. 2 (1996) 1440.

[14] E. Wehman, G. van Koten, C.J.M. Erkamp, D.M. Knotter, J.T.B.H. Jastrzebski, C.H. Stam, Organometallics 8 (1989) 94.

[15] S. Nunomoto, Y. Kawakami, Y. Yamashita, J. Org. Chem. 48 (1983) 1912. 
[16] G. Cahiez, S. Marquais, Synlett. (1993) 45.

[17] (a) M. Tamura, J. Kochi, Synthesis (1971) 303. (b) J.H. Normant, J. Organomet. Chem. Library 1 (1976) 219.

[18] S.B. Mirviss, J. Org. Chem. 54 (1989) 1948.

[19] R.E. Bowman, W.D. Fordham, J. Chem. Soc. (1952) 3945

[20] R.A. Volkmann, J.T. Davis, C.N. Meltz, J. Org. Chem. 48 (1983) 1767.

[21] G. Cahiez, M. Alami, Tetrahedron Lett. 30 (1989) 3541.

[22] H.C.L. Abbenhuis, N. Feiken, H.F. Haarman, D.M. Grove, E. Horn, A.L. Spek, M. Pfeffer, G. van Koten, Organometallics 12 (1993) 2227.
[23] E. Gallo, E. Solari, C. Floriani, A. Chiesi-Villa, C. Rizzoli, Organometallics 14 (1995) 2156.

[24] L. Brandsma, in: Preparative Acetylenic Chemistry, 2nd ed., Elsevier, Amsterdam, 1988, pp. 26 and 256.

[25] J.T.B.H. Jastrzebski, G. van Koten, M. Konijn, C.H. Stam, J. Am. Chem. Soc. 104 (1982) 5490.

[26] J.G. Donkervoort, J.L. Vicario, E. Rijnberg, J.T.B.H. Jastrzebski, H. Kooijman, A.L. Spek, G. van Koten, J. Organomet. Chem. 547 (1997) 349.

[27] H. Hiemstra, H. Wijnberg, Tetrahedron Lett. 25 (1997) 2183. 